\title{
Influence Mechanism and Evolutionary Game of Environmental Regulation on Green Port Construction
}

\author{
Gaodan Deng, Jingxiao Chen and Quanlong Liu * (B)
}

check for updates

Citation: Deng, G.; Chen, J.; Liu, Q. Influence Mechanism and

Evolutionary Game of Environmental

Regulation on Green Port

Construction. Sustainability 2022, 14, 2930. https://doi.org/10.3390/ su14052930

Academic Editor: Brantley Liddle

Received: 17 January 2022

Accepted: 26 February 2022

Published: 2 March 2022

Publisher's Note: MDPI stays neutral with regard to jurisdictional claims in published maps and institutional affiliations.

Copyright: (C) 2022 by the authors. Licensee MDPI, Basel, Switzerland. This article is an open access article distributed under the terms and conditions of the Creative Commons Attribution (CC BY) license (https:// creativecommons.org/licenses/by/ $4.0 /)$.
School of Economics and Management, China University of Mining and Technology, University Rd. 1 Xuzhou 221116, China; tb17070003b0@cumt.edu.cn (G.D.); tb19070001b0@cumt.edu.cn (J.C.)

* Correspondence: qll2016@cumt.edu.cn
Abstract: Ports are not only an important driving force for the growth of the world economy but also the main energy-consuming unit and pollution source in the world. Under the new global energy crisis and environmental deterioration situation, the international port community has put forward the concept of green port development. As a guide, the government's environmental regulation strategy can directly affect green port construction through market incentive or command control means and can also indirectly affect green port construction through the intermediary role of green innovation, industrial agglomeration and green logistics. Considering the strategic choices of the government, port enterprises and transportation enterprises, this paper constructs a tripartite evolutionary game model and considers whether the government carrying out environmental regulation is affected by the fine income and management cost, whether the willingness of port enterprises to carry out green port construction is determined by the extra construction cost and income and whether transportation enterprises choose green port logistics transportation depending on the extra income they receive. In the process of tripartite cooperation, the government's environmental regulation, port enterprises' green port construction and transportation enterprises' choice of the green port logistics transportation mode constitute the most ideal strategy combination. Finally, the paper puts forward some suggestions for the strategy selection of the three parties in order to promote the realization of the ideal strategy combination and provide a theoretical reference for the construction of green ports.

Keywords: environmental regulation; green port construction; government; port enterprises; transportation enterprises; influence mechanism; evolutionary game

\section{Introduction}

In 2019, when General Secretary Xi Jinping inspected Tianjin Port, he pointed out that "the economy needs to develop and the country needs to be strong. Transportation, especially shipping, should be strengthened first. We should strive to build a worldclass smart port and green port...", which points out the direction for China to build world-class ports. In November of the same year, the Ministry of Transport and nine other state departments jointly issued "the Guiding Opinions on the Construction of World-class Ports", which defined the overall thinking, development goals and main tasks of the construction of world-class ports and made arrangements for the high-quality development of the port industry. Under the background of the new era, China has become an internationally recognized port power in terms of port size and container throughput. However, it should also be noted that compared with the advanced level of ports in the world, China's ports still have a big gap in smart services, port city integration, green development and other aspects [1].

In addition, because the shipping industry uses a lot of fossil energy, the data of "the White Paper on Air Pollution Prevention and Control of Chinese Ships and Ports" published by the Natural Resources Defense Council (NRDC) in 2014 showed that the impact of ships and ports on the environment is far beyond people's imagination [2]. Green 
port construction for low-carbon environmental protection has thus become significant for the sustainable resolution of economic and social problems.

"Green ports" are sustainable ports that strike a good balance between environmental impact and economic benefits. At the 26th Conference of the Parties to the United Nations Framework Convention on Climate Change (COP26) in 2021, countries made unprecedented commitments to protecting forests, setting "net zero emission targets", reducing methane emissions and accelerating green technology. At the meeting, Secretary Xi put forward proposals to accelerate China's green transformation and form a " $1+\mathrm{N}$ " policy system of carbon peak and carbon neutrality. As an indispensable component in the field of transportation, ports' green transformation plays a positive role in promoting the healthy development of China's economy.

In the process of building green ports, it is ideal to cooperate with each other. It is one of the goals of the present stage to promote the construction of green ports in China and to develop world-class ports through reasonable environmental regulation strength and means. However, how can the government use environmental regulation means to supervise the green construction behavior of port enterprises, guide shipping enterprises to continue to adopt port logistics and then realize the ideal "cooperation" dynamic adjustment mechanism of government guidance, port enterprises' implementation and shipping enterprises' response? This problem is exactly the key to green port construction.

Therefore, this article focuses on this goal on the basis of assessing the influence mechanism of environmental regulation on green port construction using the method of evolutionary game by analyzing the strategic choices of the government, port enterprises and transportation enterprises in different forms. With this, favorable conditions can be created for guiding the three parties to make positive strategies so as to realize the equilibrium of tripartite joint construction of green ports, promote the high-quality green development of ports and help the port industry achieve the goal of carbon peak and carbon neutrality.

\section{Literature Review}

At present, research on green port construction mainly focuses on port enterprises, including green port operation, port management and development strategies and port performance evaluation [3]. Venturini [4], Dulebenets [5] and Peng [6] used hybrid evolutionary algorithms and port ship energy consumption prediction models to optimize berth allocation and explore the reduction strategy of port ship energy consumption so as to reduce the $\mathrm{CO}_{2}$ emissions of ships and loading and unloading equipment. Kang [7], Kim [8] and Lam [9] analyzed the specific situations of different ports around the world from the perspective of sustainable development and put forward corresponding countermeasures to improve green port operation. Under the premise of energy conservation and emission reduction, green port performance evaluations include not only economic and social factors but also environmental factors. Antão [10] developed a series of key performance indicators from occupational, health, safety, environmental and other aspects based on the perspective of port stakeholders. Wan [11] measured the process of port greening from the aspects of driving force, pressure, state, influence and reaction. Wang [12] evaluated the green efficiency of 18 ports in China by using the game cross efficiency model.

From the perspective of the government, Shao [13] discussed construction ideas and development countermeasures for ecological ports in China, from the formulation of port environmental protection policies to the planning of ecological ports. Lu [2] constructed an evolutionary game model involving the government and port enterprises, parameterized the behaviors of port city residents in the model and believed that the government could encourage port enterprises to carry out green port construction through appropriate mechanism design. $\mathrm{Xu}$ [14] constructed an evolutionary game model of emission reduction between local governments and port enterprises on the basis of compulsory emission reduction and introduced carbon tax as a penalty factor, believing that port enterprises' emission reduction under incomplete government supervision is the optimal Nash equi- 
librium strategy. Acciaro [15] believed that the green innovation of ports should involve stakeholders, including the government, and proposed an innovation research framework including several subjects. On analyzing the Port of Koper, a green port certificate holder, Elen [16] believed that the port can become more competitive through the construction of innovative green infrastructure.

Reviewing the existing research results, in terms of research methods, they focus more on exploring green port construction from the perspective of port enterprises or analysis based on the complete rationality of relevant subjects and the game between the two subjects, ignoring the fact that complete rationality is difficult to achieve in a realistic environment. Additionally, as ports serve for transportation, it is of more practical significance to consider the strategic choice of transportation enterprises in the construction of green ports. Although the existing literature discusses the government putting forward environmental regulations or mandatory cuts requirements on green port construction, since there is no known mechanism of the effects of environmental regulation on green port construction, the government, port enterprises and transportation enterprises are put in the same game system. Therefore, whether environmental regulation can push port enterprises to achieve the goal of green port construction is still questionable. In view of this, this paper integrates the bounded rationality of the government, port enterprises and transportation enterprises into a system; constructs a three-party non-cooperative evolutionary game model and explores the ideal "cooperative" game solution for green port construction with the hope of providing a theoretical basis for green port construction in China.

\section{Influence Mechanism of Environmental Regulation on Green Port Construction}

Regarding pollution prevention and control, environmental regulation is currently the most targeted and powerful tool [17]. The government can realize the requirements of environmental regulation by formulating market-oriented incentive policies, such as collection of pollution charges and environmental taxes, or command-and-control policies, such as enactment of local laws and regulations. Port enterprises can choose different coping strategies according to environmental regulation standards, such as transferring the increased costs to transport enterprises or promoting green innovation to achieve energy conservation and emission reduction. Transportation enterprises can choose whether to continue to use port transportation according to their own environmental awareness and the changes in the cost.

\subsection{Direct Influence Mechanism of Environmental Regulation on Green Port Construction}

In 2018, the Ministry of Transport formulated the "Action plan for Further Promoting green Port construction", which issued a new "Green Port Rating Evaluation Guide" (JTS/T 105-4-2020) again in 2020. Based on this standard, the China Port Association actively promotes the evaluation of green ports, starting from specialized container terminals and gradually expanding to specialized ore, coal, cruise terminals, etc. In 2020, 11 Chinese ports were rated as green ports; by 2021, there were more than 40 . The government and non-governmental organizations with binding force have promoted the construction of green ports in China with environmental regulation.

No matter what environmental regulation strategy the government uses, it will directly affect the cost and income of port enterprises. On the one hand, the environmental regulation standards issued by the government may make some small, limited capital, and heavily polluting port enterprises will be unable to maintain production and have to withdraw from the field, so the whole port industry will face a situation of reshuffle. On the other hand, the compliance cost for the remaining port enterprises to meet the environmental regulation standards will inevitably increase. If they can obtain environmental subsidies from the government, it will directly reduce taxes and fees; alternatively, if the transportation enterprises have a high awareness of environmental protection and are willing to pay extra environmental expenses and share the increased compliance cost, 
it will affect the production and operation mode of port enterprises, which will directly promote the construction of green ports. The influencing mechanism is shown in Figure 1.

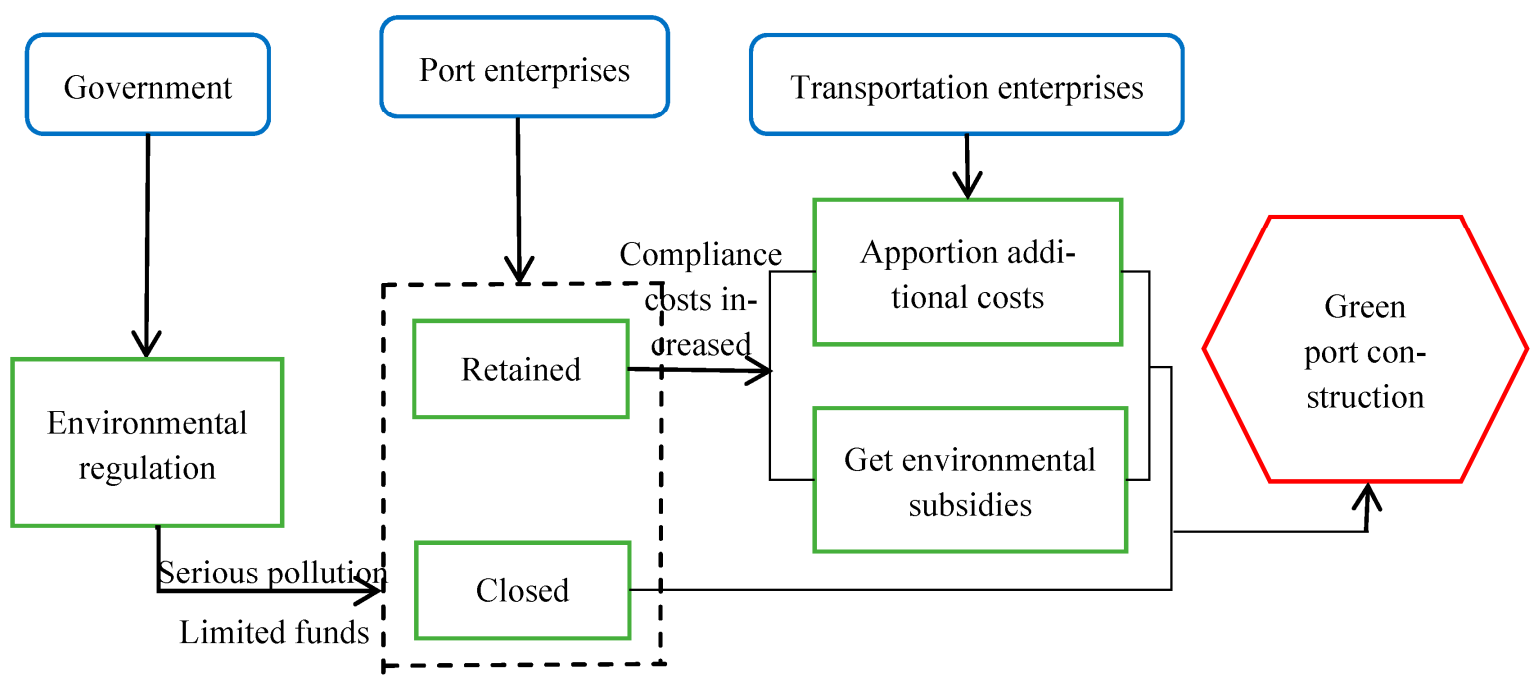

Figure 1. Direct influence mechanism of environmental regulation on green port construction. Source: Self-drawn by the author.

\subsection{Indirect Influence Mechanism of Environmental Regulation on Green Port Construction}

(1) Intermediary role of green innovation

In 2019, the "Guiding Opinions on Building a Market-oriented Green Technology Innovation System" issued by the National Development and Reform Commission and the Ministry of Science and Technology clearly stated that "a market-oriented green technology innovation system should be built".

Environmental regulations have not reached a unified understanding of green port construction through green innovation. According to existing theories, environmental regulation has both positive and negative cross-effects of "compliance cost" and "innovation supplement" [18]. On the one hand, port enterprises, as the main part of green port construction, should comply with the environmental regulation requirements and need to allocate extra funds for green innovation to achieve the goal of building a green port, such as by perfecting the existing infrastructure, optimizing the allocation of berths and improving operation equipment and pollution control technology, which will directly cause an increase in the port enterprise pollution costs. The decrease in funds for other production activities and the increase in transport costs could cause transport enterprises to abandon port transport and choose other modes of transport instead, known as the "compliance cost" effect. On the other hand, under environmental regulation, port enterprises may receive green subsidies from the government for green innovation. With the deepening of environmental protection publicity, people's consumption is also changing and green demand continues to increase. When the production process is improved, port enterprises that realize green innovation stand out more easily, improve their service level and occupy a favorable position in the competition. In this way, the profit space is broadened and enthusiasm for green innovation is aroused, known as the "innovation supplement" effect. The influence of environmental regulation on green innovation is determined by the size of the two; that is, whether environmental regulation can ultimately promote the construction of green ports depends on whether the "innovation supplement" brought to port enterprises by green innovation can make up for the cost increase from green innovation [19]. The influencing mechanism is shown in Figure 2. 


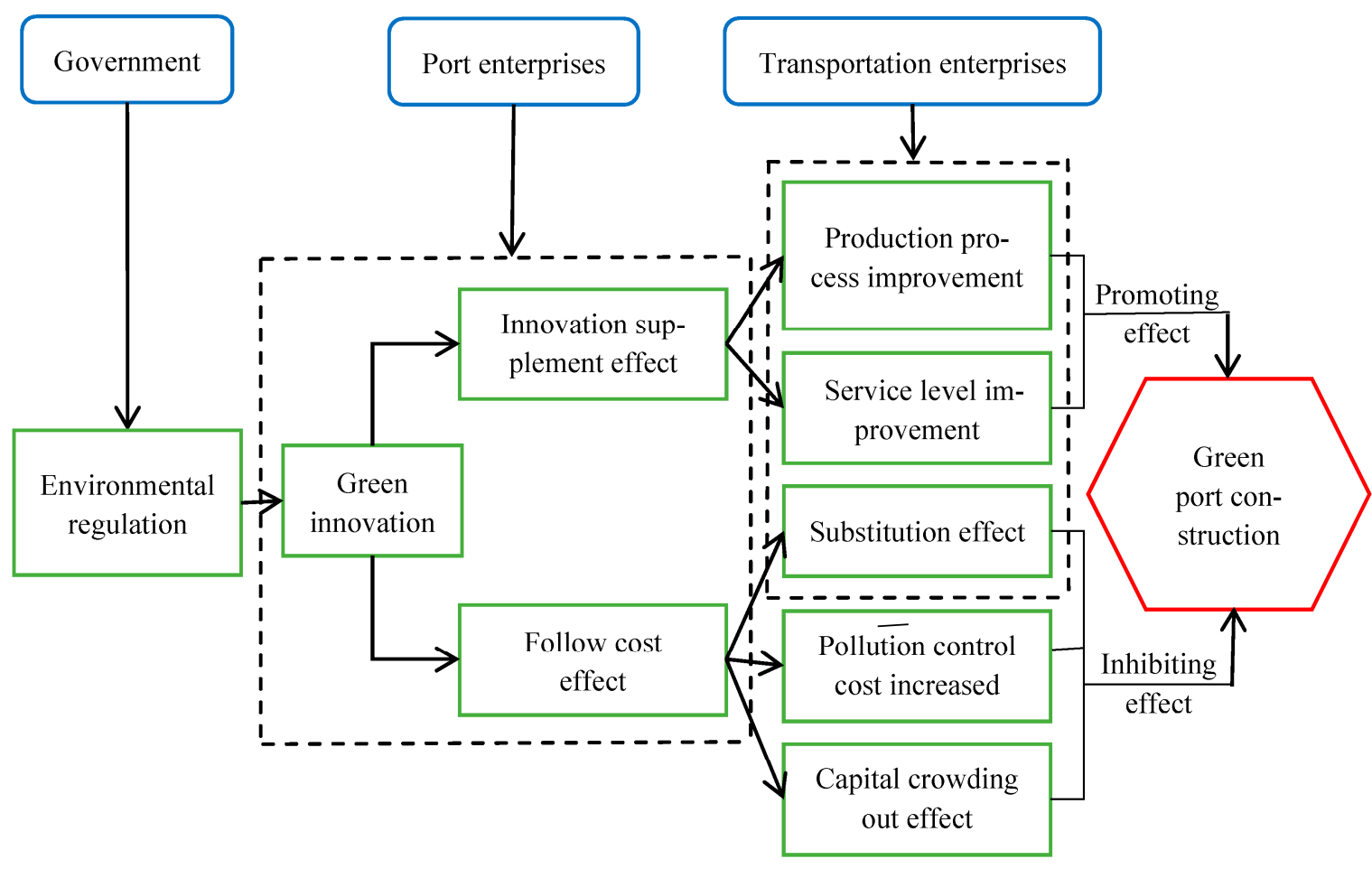

Figure 2. Indirect influence mechanism of environmental regulation mediated by green innovation on green port construction. Source: Self-drawn by the author.

\section{(2) Intermediary role of industrial agglomeration}

Many port enterprises often coexist in a port. When the scale is expanded to a certain extent, industrial agglomeration will occur, bringing the economies of scale effect. At this time, the production and operation activities of multiple enterprises in the port area are carried out simultaneously, and the amount of pollution discharged increases. Due to the environmental regulation strategy formulated by the government, the environmental governance infrastructure in the port area is fully utilized, and the pollution control cost per unit output value is reduced [20]. As more and more port enterprises gather, some enterprises may begin to pursue differentiated production and provide non-homogenous products and services in order to gain the favor of transportation enterprises. Due to the high level of information sharing, talent flow and technology transfer in the region, other port enterprises will compete to imitate, and the external positive effect will be prominent. When such activities are always carried out in a positive direction, they can reduce energy consumption, reduce pollution, improve the cleanliness level in the region and promote the construction of green ports [21]. However, due to the existence of environmental regulations, some enterprises may migrate to ports with no or weak environmental regulations, and other enterprises will follow suit and withdraw, bringing negative external effects. Therefore, the level of environmental regulation should be maintained within a reasonable range so as to better play the intermediary role of industrial agglomeration. The influencing mechanism is shown in Figure 3.

Taking the industrial agglomeration of China's five major coastal port groups (Bohai Rim, Yangtze River Delta, southeast coastal, Pearl River Delta and southwest coastal) as an example, the agglomeration effect forms a complementary, cooperative and interactive port environment, which makes the ports produce a huge agglomeration economic radiation effect. This not only promotes the development of port enterprises but also drives the hinterland economy to spread around the port group and inland and promotes the development of the national economy. Over the years, the scale of China's ports has steadily come to rank first in the world. China holds seven of the top 10 ports in terms of cargo 
throughput and container throughput in the world. Tianjin Port, Shanghai Port, Zhoushan Port, etc., have an obvious industrial agglomeration effect.

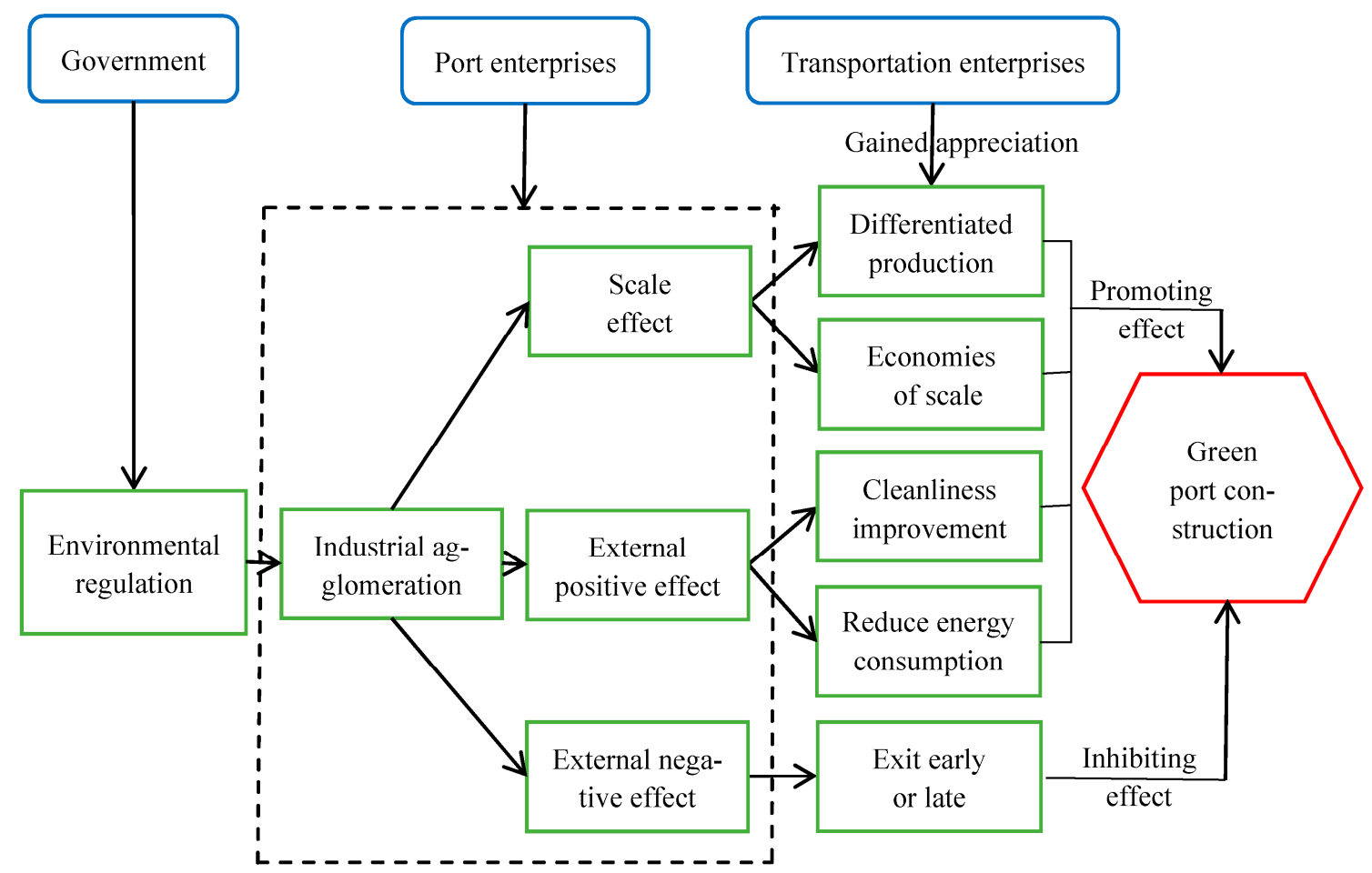

Figure 3. Indirect influence mechanism of environmental regulation mediated by industrial agglomeration on green port construction. Source: Self-drawn by the author.

\section{(3) Intermediary role of green logistics "forced"}

With the improvement of living standards, consumers are pursuing a higher product quality, and the concepts of "organic" and "pollution-free" are deeply rooted in people's hearts. When exporting, the European Union, the United States, Japan and other developed countries have relatively higher environmental protection standards. Their requirements for green products are not only reflected in the production and processing of raw materials but also extend to the logistics. The growth rate of carbon emissions in the logistics industry is negatively correlated with China's export trade flow [22]. In the port, it is necessary to carry out logistics loading, unloading and handling activities; ship docking and scheduling and the conversion of different transportation modes, short-term storage of products, etc. Therefore, transportation enterprises urgently need a low-emission and pollution-free port operation mode and seek cooperation with port enterprises with green technology. Under the demand orientation, green logistics will "force" port enterprises to carry out pollution control and green technology innovation, so as to indirectly achieve the goal of green port construction. The influencing mechanism is shown in Figure 4. 


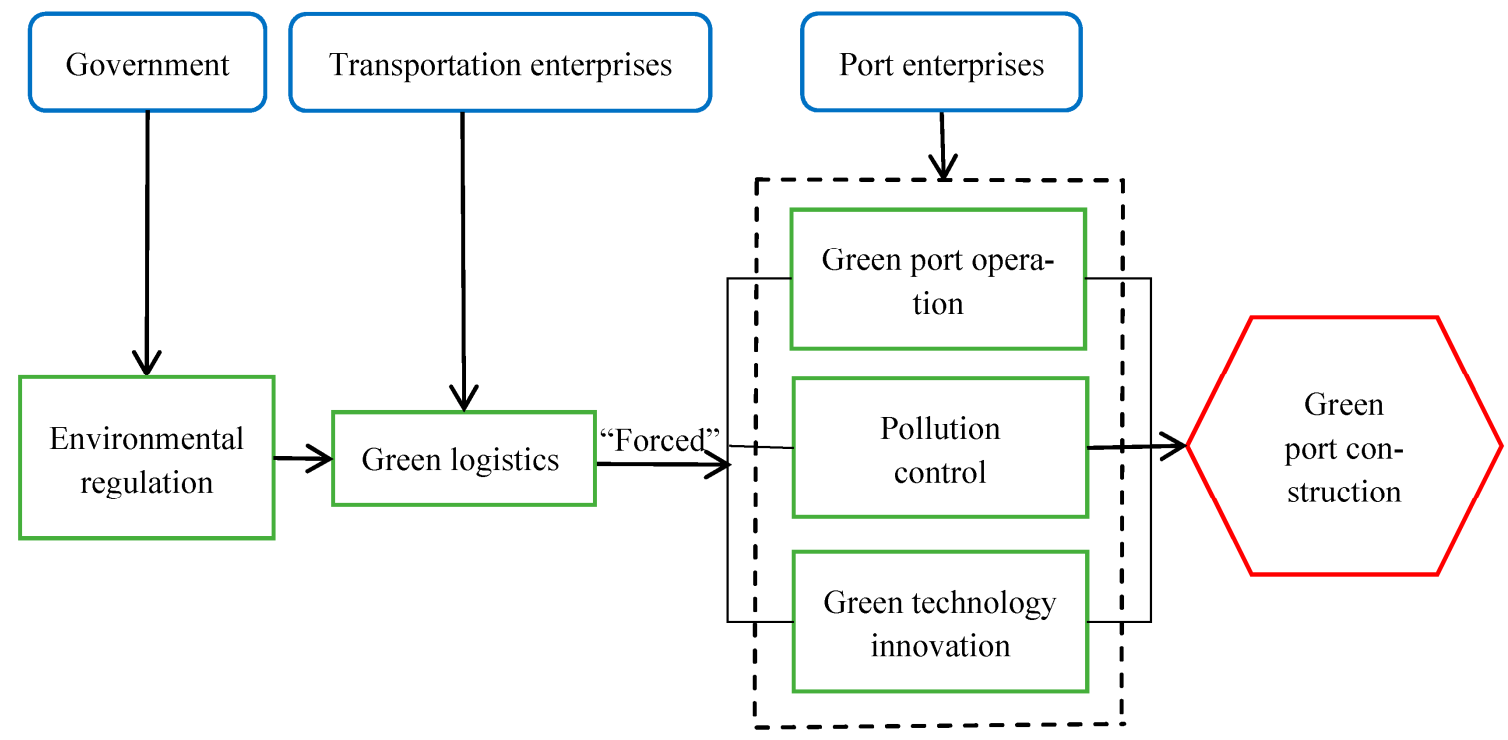

Figure 4. Indirect influence mechanism of environmental regulation mediated by green logistics "forced" on green port construction. Source: Self-drawn by the author.

\section{Evolutionary Game of Green Port Construction under Environmental Regulation 4.1. Basic Assumptions and Model Construction}

According to stakeholder [23,24] and evolutionary game theory [25], the following basic assumptions are made:

Assumption 1: The government, port enterprises and transportation enterprises, the main stakeholders of green port construction, constitute an evolutionary game system. These three parties are all limited rational individuals with a learning ability and have their own behavior choices and rights from different interest perspectives [26].

Assumption 2: The government, port enterprises and transportation enterprises have two behavior choices: whether the government regulates the environment, whether the port enterprises construct green ports and whether the transportation enterprises choose to adopt the mode of green port transportation. $x, y$ and $z$ represent the selection probability of different subjects, and $x, y$ and $z \in[0,1]$. They are all functions of time, $t$. During the game, the government, port enterprises and transportation enterprises adjust their strategies through continuous learning until an equilibrium is finally achieved.

Based on the above assumptions, the game tripartite payment matrix was constructed, as shown in Table 1. Related parameters were set as follows:

Table 1. Payment matrix of government, port enterprises and transportation enterprises.

\begin{tabular}{ccccc}
\hline & \multicolumn{2}{c}{ Port enterprises construct green port $(y)$} & Port enterprises do not construct green port $(1-y)$ \\
\cline { 2 - 5 } & $\begin{array}{c}\text { Transportation } \\
\text { enterprises adopt green } \\
\text { port logistics }(z)\end{array}$ & $\begin{array}{c}\text { Transportation } \\
\text { enterprises do not adopt } \\
\text { green port logistics }(1-z)\end{array}$ & $\begin{array}{c}\text { Transportation } \\
\text { enterprises adopt } \\
\text { green port logistics }(z)\end{array}$ & $\begin{array}{c}\text { Transportation } \\
\text { enterprises do not adopt } \\
\text { green port logistics }(1-z)\end{array}$ \\
\hline $\begin{array}{c}\text { The government regulates } \\
\text { environment }(x)\end{array}$ & $P_{1}-C_{1}$ & $P_{1}-C_{1}$ & $P_{2}-C_{1}+\Delta C-R_{1}$ & $P_{2}-C_{1}+\Delta C-R_{1}$ \\
$P_{3}+\Delta P_{2}-C_{2}$ & $P_{3}-C_{2}$ & $P_{4}-\Delta C-R_{2}$ & $P_{4}-\Delta C$ \\
$R_{1}+R_{2}$ & $P_{2}-C_{5}$ & $P_{2}-C_{5}$ \\
The government does not & $W+\Delta P_{1}$ & $W$ & $P_{2}$ & $R_{2}$ \\
regulate environment $(1-x)$ & $P_{3}+P_{2}-C_{3}-C_{5}$ & $P_{1}-C_{3}-C_{5}+C_{3}+C_{4}$ & $P_{3}-C_{2}+C_{3}+C_{4}$ & 0 \\
\hline
\end{tabular}

Data source: Calculated using the above assumptions. 
Assuming that the revenue source of the government is tax, when the port enterprises construct green ports, the revenue of the government is $P_{1}$. Otherwise, the revenue is $P_{2}$, and $P_{1}<P_{2}$ in a certain period of time. When the government regulates the environment, it needs to invest more manpower, material resources and financial resources for supervision, resulting in an additional management cost, $C_{1}$.

Similarly, when port enterprises construct green ports, they will gain $P_{3}$. At this time, they need to pay extra costs to control pollution, purchase environmental protection equipment or start green innovation [27]; that is, an additional construction cost, $C_{2}$, is generated. Otherwise, the revenue is $P_{4}$. As there is $C_{2}, P_{3}<P_{4}$.

If port enterprises construct green ports and transport enterprises are willing to adopt the port transportation mode under green logistics to support environmental protection, the external image of the enterprise can be improved and social recognition or tax incentives can be obtained [28]. The additional income generated by this part is $\Delta P_{1}$. This behavior will also have an incentivizing effect on port enterprises, which can be more confident to invest in green port construction, and the additional income of this part is $\Delta P_{2}$. At the same time, due to the increasing cost, port enterprises will require subsidies [29] and will transfer part of the extra $\operatorname{cost} C_{2}$ to the government as $C_{3}$ and the other part to the transportation enterprises as $C_{4}$ in the way of raising the cost, and $C_{2} \geq C_{3}+C_{4}$. In addition, as long as port enterprises construct green ports, regardless of there being government regulations or not, transportation enterprises can enjoy the improved port production and living environment and obtain environmental welfare, $W$.

When the government regulates the environment but the port enterprises refuse to construct green ports, they will be punished [30], resulting in fines, $\Delta C$. Under this premise, the port environment is damaged. Regardless of whether the transportation enterprises choose a green port transportation mode or not, they will be in an inferior competitive position in international logistics transportation. The government will give them pollution compensation, $R_{1}$.

When transport enterprises have green logistics needs but port enterprises cannot meet them, regardless of the government's environmental regulation status, in order to seek continuous cooperation with transport enterprises, the port enterprises will promise to reduce costs and give them pollution compensation, $R_{2}$.

Whenever the government does not regulate the environment, it will be accused of inaction, which will negatively affect the image of the government and produce reputation costs, $C_{5}$.

\subsection{Evolutionary Stability Analysis of the Game Model}

Due to the asymmetry of information acquisition of the government, port enterprises and transportation enterprises under environmental regulation, the three parties will adjust their decisions dynamically through continuous learning and by mastering the information of other parties during the game. According to the above payment matrix, the replication dynamic equations of the government, port enterprises and transportation enterprises can be solved respectively.

(1) Evolutionary stability analysis of government

The expected utility and the population utility of the environment being regulated or not regulated by the government are

$$
\begin{gathered}
U_{g}=y z\left(P_{1}-C_{1}\right)+y(1-z)\left(P_{1}-C_{1}\right)+(1-y) z\left(P_{2}-C_{1}+\Delta C-R_{1}\right)+(1-y)(1-z)\left(P_{2}-C_{1}+\Delta C-R_{1}\right) \\
U_{\bar{g}}=y z\left(P_{1}-C_{3}-C_{5}\right)+y(1-z)\left(P_{1}-C_{3}-C_{5}\right)+(1-y) z\left(P_{2}-C_{5}\right)+(1-y)(1-z)\left(P_{2}-C_{5}\right) \\
\bar{U}_{g}=x U_{g}+(1-x) U_{\bar{g}}
\end{gathered}
$$

According to the Malthusian dynamic equation, the growth rate $\frac{d x}{d t}$ of the government's environmental regulation strategy is proportional to the difference between the expected 
utility of selecting this strategy and the population utility. Therefore, the government's replication dynamic equation is

$$
F(x)=\frac{d x}{d t}=x\left(U_{g}-\bar{U}_{g}\right)=x(1-x)\left(U_{g}-U_{\bar{g}}\right)=x(1-x)\left[y\left(C_{3}-\Delta C+R_{1}\right)-C_{1}+\Delta C-R_{1}+C_{5}\right]
$$

i. When $y=\frac{C_{1}-\Delta C+R_{1}-C_{5}}{C_{3}-\Delta C+R_{1}}, F(x) \equiv 0$. At this point, no matter the value of $x$, the government's strategy choice remains in a stable state.

ii. When $y>\frac{C_{1}-\Delta C+R_{1}-C_{5}}{C_{3}-\Delta C+R_{1}}, F^{\prime}(0)>0, F^{\prime}(1)<0$. At this point, $x=1$ is the evolutionary equilibrium point, and the government will tend to reg-ulate the environment.

iii. When $y<\frac{C_{1}-\Delta C+R_{1}-C_{5}}{C_{3}-\Delta C+R_{1}}, F^{\prime}(0)<0, F^{\prime}(1)>0$. At this point, $x=0$ is the evolutionary equilibrium point, and the government will tend not to regulate the environment.

Based on the analysis of the above inequality, in order to obtain state "ii" below and encourage the government to regulate the environment, reasonable planning can be used to reduce the management cost of environmental regulation by the government, increase the penalty of port enterprises that do not construct green ports and reduce pollution compensation for transportation enterprises and increase the reputation cost of not regulating the environment for the government.

(2) Evolutionary stability analysis of port enterprises

Based on the above analysis, the replication dynamic equation of port enterprises is

$$
\begin{array}{r}
F(y)=\frac{d y}{d t}=y\left(U_{p}-\bar{U}_{p}\right)=y(1-y)\left(U_{p}-U_{\bar{p}}\right) \\
=y(1-y)\left[z\left(\Delta P_{2}+R_{2}\right)+x\left(\Delta C-C_{3}-C_{4}\right)+P_{3}-P_{4}-C_{2}+C_{3}+C_{4}\right]
\end{array}
$$

i. When $x=\frac{P_{4}+C_{2}-P_{3}-C_{3}-C_{4}-z\left(\Delta P_{2}+R_{2}\right)}{\Delta C-C_{3}-C_{4}}, F(y) \equiv 0$. At this point, no matter the value of $y$, port enterprises' strategic choice remains in a stable state.

ii. When $x>\frac{P_{4}+C_{2}-P_{3}-C_{3}-C_{4}-z\left(\Delta P_{2}+R_{2}\right)}{\Delta C-C_{3}-C_{4}}, F^{\prime}(0)>0, F^{\prime}(1)<0$. At this point, $y=1$ is the evolutionary equilibrium point, and port enterprises will be inclined to construct green ports.

iii. When $x<\frac{P_{4}+C_{2}-P_{3}-C_{3}-C_{4}-z\left(\Delta P_{2}+R_{2}\right)}{\Delta C-C_{3}-C_{4}}, F^{\prime}(0)<0, F^{\prime}(1)>0$. At this point, $y=0$ is the evolutionary equilibrium point, and port enterprises will tend not to build green ports.

Based on the analysis of the above inequality, in order to obtain state "ii" below and encourage port enterprises to build green ports, the cost of green port construction can be reduced by government subsidies or technological innovation, the income of port enterprises from green port construction can be improved by tax incentives, the enthusiasm of transportation enterprises to choose green port logistics can be promoted and the punishment by the government for port enterprises that do not construct green ports can be increased. Furthermore, to increase the additional income obtained by port enterprises, the pollution compensation can be increased for reducing expenses in order to seek continued cooperation with transport enterprises when port enterprises do not construct green ports.

(3) Evolutionary stability analysis of transport enterprises

Similarly, the replication dynamic equation of transportation enterprises is

$$
F(z)=\frac{d z}{d t}=z\left(U_{t}-\bar{U}_{t}\right)=z(1-z)\left(U_{t}-U_{\bar{t}}\right)=z(1-z)\left[y\left(\Delta P_{1}-R_{2}\right)+R_{2}\right]
$$

i. When $y=\frac{R_{2}}{R_{2}-\Delta P_{1}}, F(z) \equiv 0$. At this point, no matter the value of $z$, the transportation enterprise's strategy choice is in a stable state.

ii. When $y \neq \frac{R_{2}}{R_{2}-\Delta P_{1}}$, to take $F(z)=0$, let $z=0$ or $z=1$. At this point, the transportation enterprise's strategy choice is in a stable state. 
Since $F^{\prime}(z)=(1-2 z)\left[y\left(\Delta P_{1}-R_{2}\right)+R_{2}\right]$, when $z \in(0,1)$, the stable state of transportation enterprises' strategic choice depends on the form of line $L=y\left(\Delta P_{1}-R_{2}\right)+R_{2}$. That is:

a When $L=y\left(\Delta P_{1}-R_{2}\right)+R_{2}>0, F^{\prime}(0)>0, F^{\prime}(1)<0$. At this point, it is a stable strategy for transportation enterprises to adopt the green port transportation mode. On the contrary, it is an unstable strategy.

b When $L=y\left(\Delta P_{1}-R_{2}\right)+R_{2}<0$ :

If $y<\frac{R_{2}}{R_{2}-\Delta P_{1}}$, then $F^{\prime}(0)>0, F^{\prime}(1)<0$. At this point, $z=1$ is the evolutionary equilibrium point, and transportation enterprises tend to adopt the green port transportation mode.

If $y>\frac{R_{2}}{R_{2}-\Delta P_{1}}$, then $F^{\prime}(0)<0, F^{\prime}(1)>0$. At this point, $z=0$ is the evolutionary equilibrium point, and transportation enterprises tend not to adopt the green port transportation mode.

Based on the analysis of the above inequality, transportation enterprises can be encouraged to adopt the green port logistics transportation mode by market regulation and increasing the pollution compensation for the port enterprises when they do not construct green ports. Subsidies, tax preferences and intensified propaganda can be used to increase the additional benefits that the transportation enterprises can obtain by adopting the green port transportation mode.

\subsection{Asymptotic Stability Analysis of Game Model}

On the premise of bounded rationality, Equations (4)-(6) illustrate the process by which the government, port enterprises and transportation enterprises adjust their strategy selection through continuous learning in the game. In order to further explore the equilibrium point of the three parties in the steady-state game, let the dynamic equation of replication be 0 , namely

$$
A=\left\{\begin{array}{l}
F(x)=0 \\
F(y)=0 \\
F(z)=0
\end{array}\right.
$$

According to Equation (7), it can be calculated that there are nine equilibrium points in system $A$ : $(0,0,0),(0,0,1),(0,1,0),(0,1,1),(1,0,0),(1,0,1),(1,1,0),(1,1,1)$ and $\left(x^{\prime}, y^{\prime}, z^{\prime}\right)$. Among them, $\left(x^{\prime}, y^{\prime}, z^{\prime}\right)$ is the solution of system $B$, namely

$$
B=\left\{\begin{array}{l}
y\left(C_{3}-\Delta C+R_{1}\right)-C_{1}+\Delta C-R_{1}+C_{5}=0 \\
z\left(\Delta P_{2}+R_{2}\right)+x\left(\Delta C-C_{3}-C_{4}\right)+P_{3}-P_{4}-C_{2}+C_{3}+C_{4}=0 \\
y\left(\Delta P_{1}-R_{2}\right)+R_{2}=0
\end{array}\right.
$$

(1) Analysis of equilibrium point $(0,0,0)$

Taking the equilibrium point $(0,0,0)$ as an example, the Jacobian matrix is

$$
J=\left[\begin{array}{ccc}
-C_{1}+\Delta C-R_{1}+C_{5} & 0 & 0 \\
0 & P_{3}-P_{4}-C_{2}+C_{3}+C_{4} & 0 \\
0 & 0 & R_{2}
\end{array}\right]
$$

According to the Lyapunov stability condition, when all eigenvalues $\lambda$ of the Jacobian matrix satisfy $\lambda<0$, the equilibrium point is asymptotically stable; when one or two eigenvalues $\lambda$ satisfy $\lambda>0$, the equilibrium point is a saddle point; and when all eigenvalues $\lambda$ satisfy $\lambda>0$, the equilibrium point is an unstable point.

Since $P_{3}-P_{4}-C_{2}+C_{3}+C_{4}=\left(P_{3}-P_{4}\right)+\left(C_{3}+C_{4}-C_{2}\right)<0$, and $R_{2}$ is a definite positive number, $R_{2}>0$ is satisfied. Therefore, the equilibrium point $(0,0,0)$ is a saddle point.

(2) Analysis of other equilibrium points

Similarly, the asymptotic stability of other equilibrium points is shown in Table 2. 
Table 2. Asymptotic stability of equilibrium points.

\begin{tabular}{|c|c|c|c|c|}
\hline \multirow{2}{*}{ Equilibrium Points } & \multicolumn{3}{|c|}{ Eigenvalues } & \multirow{2}{*}{ Asymptotic Stability } \\
\hline & $\lambda_{1}$ & $\lambda_{2}$ & $\lambda 3$ & \\
\hline$(0,0,0)$ & $\Delta C-C_{1}-R_{1}+C_{5}$ & $P_{3}-P_{4}-C_{2}+C_{3}+C_{4}<0$ & $R_{2}>0$ & Saddle point \\
\hline$(0,0,1)$ & $\Delta C-C_{1}-R_{1}+C_{5}$ & $\Delta P_{2}+R_{2}+P_{3}-P_{4}-C_{2}+C_{3}+C_{4}$ & $-R_{2}<0$ & Saddle point or stable point \\
\hline$(0,1,0)$ & $C_{3}-C_{1}+C_{5}$ & $P_{4}-P_{3}+C_{2}-C_{3}-C_{4}>0$ & $\Delta P_{1}>0$ & Saddle point or unstable point \\
\hline$(0,1,1)$ & $C_{3}-C_{1}+C_{5}$ & $P_{4}-\Delta P_{2}-R_{2}-P_{3}+C_{2}-C_{3}-C_{4}$ & $-\Delta P_{1}<0$ & Saddle point or stable point \\
\hline$(1,0,0)$ & $C_{1}-\Delta C+R_{1}-C_{5}$ & $\Delta C+P_{3}-P_{4}-C_{2}$ & $R_{2}>0$ & Saddle point or unstable point \\
\hline$(1,0,1)$ & $C_{1}-\Delta C+R_{1}-C_{5}$ & $\Delta P_{2}+R_{2}+\Delta C+P_{3}-P_{4}-C_{2}$ & $-R_{2}<0$ & Saddle point or stable point \\
\hline$(1,1,0)$ & $C_{1}-C_{3}-C_{5}$ & $P_{4}+C_{2}-\Delta C-P_{3}$ & $\Delta P_{1}>0$ & Saddle point or unstable point \\
\hline$(1,1,1)$ & $C_{1}-C_{3}-C_{5}$ & $P_{4}+C_{2}-\Delta P_{2}-R_{2}-\Delta C-P_{3}$ & $-\Delta P_{1}<0$ & Saddle point or stable point \\
\hline
\end{tabular}

According to the above analysis, there are four possible combinations, namely $(0,0,1)$, $(0,1,1),(1,0,1)$ and $(1,1,1)$, which can become stable strategies in the evolutionary game. It was found that no matter what choice the government and port enterprises make, it is an ideal state for transportation enterprises to choose the green port logistics transportation mode. Therefore, $(0,1,1)$ and $(1,1,1)$ are more ideal strategic combinations for port enterprises to fully participate in the construction of green ports.

(3) Analysis of equilibrium point $(0,1,1)$

By analyzing the equilibrium point $(0,1,1)$, it was found that $C_{3}-C_{1}+C_{5}<0$ is one of the necessary conditions to make it a progressive stable point. That is, it requires the government to increase the regulatory cost of environmental regulation, and when the government does not regulate the environment, the reputation cost will decrease, which is contrary to the actual situation. Therefore, this strategy combination is not considered here.

(4) Analysis of equilibrium point $(1,1,1)$

To make the equilibrium point $(1,1,1)$ an asymptotically stable point, both $C_{1}-C_{3}-$ $C_{5}<0$ and $P_{4}+C_{2}-\Delta P_{2}-R_{2}-\Delta C-P_{3}<0$ should be satisfied. That is, it is required to meet $C_{1}<C_{3}+C_{5}$ and $P_{4}-\left(R_{2}+\Delta C\right)<P_{3}+\Delta P_{2}-C_{2}$.

By analyzing the above inequality, the following can be found:

i. When the regulatory cost of environmental regulation by the government is lower than the sum of the reputation cost caused by criticism and the green port construction cost transferred by port enterprises, the government will choose environmental regulation.

ii. When the difference between the revenue obtained by the port enterprises when they do not construct the green port and the sum of pollution compensation to the transportation enterprise and the fines is lower than the difference between the sum of their own revenues and extra income and the cost of green port construction, port enterprises will choose green port construction.

This is consistent with the actual situation; thus, it can be seen that the equilibrium point $(1,1,1)$ is the most ideal strategy combination.

\section{Conclusions and Suggestions}

\subsection{Conclusions}

General Secretary Xi pointed out that "an economic power must be a maritime power and a shipping power". Promoting a port from "large" to "strong", making the port stronger and better and promoting the port development mode type from "scale and speed" to "quality and efficiency" are important ways to build green ports at present and also guarantee the high-quality development of the port industry.

By analyzing the influence mechanism of environmental regulation on green port construction, a tripartite evolutionary game model of government, port enterprises and transportation enterprises was established, and the following conclusions can be drawn: 
(1) Based on the requirements of environmental regulation, the government can directly require port enterprises to construct green ports by administrative order or incentive means by formulating relevant policies, systems or indicators. It is also possible to promote green port construction indirectly by adjusting the direction to promote green innovation and industrial agglomeration in the port industry or guiding the intermediary role of green logistics "forced" in relevant industries.

(2) The factors that affect whether the government adopts environmental regulations mainly include the comparison between the fine income and management costs. Only when the difference between the two is positive will the government adopt environmental regulation strategies; otherwise, the government will not act. After reaching a certain level of pollution, public criticism will lead to an increase in reputation costs, which will also prompt the government to adopt the strategies.

(3) The factors that influence whether port enterprises construct green ports are determined by the extra costs and benefits generated by green port construction. When the extra construction cost is lower and the benefit is higher, port enterprises will be inclined to construct green ports. In addition, the strong will of the government to regulate the environment will also encourage port enterprises to construct green ports.

(4) Transportation enterprises' choice of green port logistics transportation mode is determined by the extra income they obtain. When the utility of this mode increases, transportation enterprises will be encouraged to choose the green transportation mode, thus putting green port construction into practice and achieving a stable equilibrium state of the three-party game system.

(5) The equilibrium point $(1,1,1)$ is the most ideal strategy combination, indicating that in the process of green port construction, the government, port enterprises and transportation enterprises should maintain full cooperation, give full play to their own advantages and constantly strengthen the awareness of environmental protection so as to achieve a win-win situation among the three parties.

\subsection{Suggestions}

Based on the above analysis and conclusion, the following suggestions are put forward for green port construction:

(1) The government should reasonably set the intensity of environmental regulations and the level of punishment for port enterprises when they do not construct green ports and make dynamic adjustments according to the implementation results. The government is the guide of green port construction and plays a leading role in the initial stage of construction. It can encourage port enterprises to partake in green innovation by means of subsidies and tax incentives. It is also an effective way to strengthen the publicity of environmental protection concepts, improve the cognition level of transportation enterprises and implement appropriate incentives to adopt green transportation behavior.

(2) Port enterprises should improve their awareness of environmental protection, actively build green ports and occupy a favorable competitive position in green port transportation through the means of green technology innovation, such as improving the utilization rate of environmental protection equipment and reducing pollution control costs. In addition, green logistics can be promoted to improve the identity of transport enterprises, attract them to adopt more environmentally friendly logistics transportation methods and increase marginal utility.

(3) Transportation enterprises present the main demand in green port logistics, and their strategy will have a direct impact on the decision-making of port enterprises. Therefore, transportation enterprises should enhance their awareness of environmental protection, expand green demand and improve the enthusiasm of adopting green logistics transportation modes. In addition, transport enterprises should also assume the market supervision responsibility, supervise the green construction behavior of port enterprises, make joint efforts for the promotion of green port construction and realize the goal of building a world-class port as soon as possible. 
Due to the length and the authors' knowledge level, this article is not detailed enough in sorting out the influence mechanism of environmental regulation on green port construction. The parameters set in the evolutionary game part still need to be improved, and the calculation results can be further extended or simulated. Improving the green development system, testing the effect of green development and building artificial intelligence-based smart ports are important research directions for the future.

Author Contributions: Formal analysis, J.C.; Funding acquisition, Q.L.; Methodology, G.D.; Writingoriginal draft, G.D.; Writing-review \& editing, Q.L. All authors have read and agreed to the published version of the manuscript.

Funding: This work was supported by the Fundamental Research Funds for the Central Universities (grant no. 2020ZDPYMS29).The APC was funded by the fund.

Institutional Review Board Statement: Not applicable.

Informed Consent Statement: Not applicable.

Data Availability Statement: Not applicable.

Acknowledgments: The authors wish to thank Xinchun Li for his support in writing and revising the article and the anonymous reviewers for their suggestions, which were most useful in revising the paper.

Conflicts of Interest: The authors declare no conflict of interest.

\section{References}

1. Chu, B. Accelerate the construction of world-class ports and better serve the major national strategies. China Water Transport News, 18 December 2019.

2. Lu, B.; Wang, H.P. The countermeasures of government promoting green port construction based on evolutionary game. East China Econ. Manag. 2017, 31, 153-159.

3. Zhen, L.; Zhuge, D.; Wang, X.F. Review on green port and shipping management. Syst. Eng.-Theory Pract. 2020, 40, $2037-2050$.

4. Venturini, G.; Iris, Ç.; Kontovas, C.A.; Larsen, A. The multi-port berth allocation problem with speed optimization and emission considerations. Transp. Res. Part D Transp. Environ. 2017, 5, 142-159. [CrossRef]

5. Dulebenets, M.A.; Moses, R.; Ozguven, E.E.; Vanli, A. The minimizing carbon dioxide emissions due to container handling at marine container terminals via hybrid evolutionary algorithms. IEEE Access 2017, 5, 8131-8147. [CrossRef]

6. Peng, Y.; Liu, H.; Li, X.; Huang, J.; Wang, W. Machine learning method for energy consumption prediction of ships in port considering green ports. J. Clean. Prod. 2020, 264, 121564. [CrossRef]

7. Kang, D.; Kim, S. Conceptual model development of sustainability practices: The case of port operations for collaboration and governance. Sustainability 2017, 9, 2333. [CrossRef]

8. Kim, S.; Chiang, B.G. The role of sustainability practices in international port operations:An analysis of moderation effect. J. Korea Trade 2017, 21, 125-144. [CrossRef]

9. Lam, J.S.L.; Notteboom, T. The greening of ports: A comparison of port management tools used by leading ports in Asia and Europe. Transp. Rev. 2014, 34, 169-189. [CrossRef]

10. Antão, P.; Calderón, M.; Puig, M.; Michail, A.; Wooldridge, C.; Darbra, R.M. Identification of occupational health, safety, security(OHSS) and environment performance indicators in port areas. Saf. Sci. 2016, 85, 266-275. [CrossRef]

11. Wan, C.; Zhang, D.; Yan, X.; Yang, Z. A novel model for the quantitative evaluation of green port development:A case study of major ports in China. Transp. Res. Part D Transp. Environ. 2018, 61, 431-443. [CrossRef]

12. Wang, L.; Zhou, Z.; Yang, Y.; Wu, J. Green efficiency evaluation and improvement of Chinese ports: A cross-efficiency model. Transp. Res. Part D Transp. Environ. 2020, 88, 102590. [CrossRef]

13. Shao, C.F.; Ju, M.T.; Chu, C.L. Construction ideas and development countermeasures of ecological port in China. J. Ecol. 2008, 28, 5601-5609.

14. Xu, Y.; Meng, Y.P. Evolutionary Game between government and port enterprises under compulsory emission reduction. J. Univ. Sci. Technol. China 2019, 49, 762-772.

15. Acciaro, M.; Vanelslander, T.; Sys, C.; Ferrari, C.; Roumboutsos, A.; Giuliano, G.; Lam, J.S.; Kapros, S. Environmental sustainability in seaports: A framework for successful innovation. Marit. Policy Manag. 2014, 41, 480-500. [CrossRef]

16. Elen, T.; Marina, Z. Improvement of the sustainability of ports logistics by the development of innovative green infrastructure solutions. Transp. Res. Procedia 2020, 45, 539-546.

17. Li, Y.; Hu, Z.Y.; He, B.Y. Analysis on the mechanism and effect of environmental regulation on green economic development. China Soft Sci. 2020, 9, 26-38. 
18. Kang, P.H.; Ru, S.F. Decomposition of bilateral effect of green innovation in environmental regulation. China Popul. Resour. Environ. 2020, 30, 93-104.

19. Fan, D.; Sun, X.T. Environmental regulation, green technological innovation and green economic growth. China Popul. Resour. Environ. 2020, 30, 105-115.

20. Lei, Y.T.; Zhang, S.W.; Sun, J.J. The influence mechanism and empirical study of environmental regulation on green transformation of manufacturing industry. Sci. Technol. Prog. Policy 2020, 37, 63-70.

21. Wang, L.M.; Zhao, Y.L.; Wang, S. Research on the impact of China's high-tech industrial agglomeration model on the efficiency of green innovation. Manag. Mod. 2022, 1, 17-23.

22. Li, H.; Chen, L.Z. The Influence of green Logistics development level on China's export Trade: A case study of Portuguesespeaking countries. Asia-Pac. Econ. Rev. 2017, 5, 78-83+175.

23. Donaldson, T.; Preston, L.E. The stakeholder theory of the corporation: Concepts, evidence, and implication. Acad. Manag. Rev. 1995, 20, 65-91. [CrossRef]

24. Li, W.H.; Li, N.; Liu, F. Three parties'evolutionary game of stakeholders in green technology innovation and their simulation. Oper. Res. Manag. 2021, 30, 216-224.

25. Weibull, J.W. Evolutionary Game Theory; Shanghai People's Publishing House: Shanghai, China, 2006.

26. Fan, H.W.; Chang, Z.; Fu, K. Research on subsidy game of port enterprises' green technology adoption under carbon quota constraint. J. Dalian Marit. Univ. 2021, 1-10. Available online: https://kns.cnki.net/kcms/detail/21.1360.U.20211108.1348.002. html (accessed on 8 November 2021).

27. Wang, P.; Liu, S.Q. Evolutionary game study of green technology innovation under market oriented mechanism considering the additional utility of consumers to green products. Econ. Probl. 2022, 1,67-77.

28. Xu, F.W.; Ding, Y.D.; Zhang, Z.F. Evolutionary game analysis of green supply chain considering consumers' green preference under government regulation. Environ. Sci. Manag. 2021, 46, 5-10.

29. Lu, C.; Cheng, H.F.; Cai, J.H. Evolutionary game analysis: Impacts of government subsidies on manufacturers' green R\&D under peer incentive mechanism. Chin. J. Manag. 2022, 19, 93-101.

30. He, Z.; Qu, J.J.; Li, B. Evolutionary game analysis of cooperative innovation behaviors of green supply chain enterprises considering government rewards and punishments. Ecol. Econ. 2021, 37, 62-70. 